\title{
Base Program on Energy Related Research
}

\author{
Quarterly Report
}

\section{August 1 - October 31, 1994}

\section{RECEIVED}

MAR 03 \%997.

OSTI

Work Performed Under Contract No.: DE-FC21-93MC30126

For

U.S. Department of Energy

Office of Fossil Energy

Morgantown Energy Technology Center

P.O. Box 880

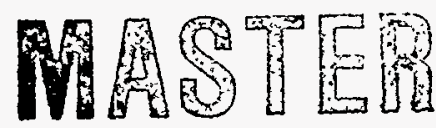

Morgantown, West Virginia 26507-0880

By

Western Research Institute

365 No. 9th Street

Laramie, Wyoming 82070-3380

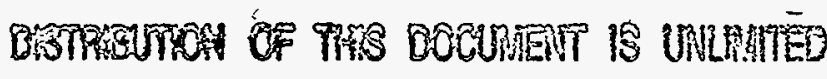




\section{DISCLAIMER}

Portions of this document may be illegible in electronic image products. Images are produced from the best available original document. 


\section{Disclaimer}

This report was prepared as an account of work sponsored by an agency of the United States Government. Neither the United States Government nor any agency thereof, nor any of their employees, makes any warranty, express or implied, or assumes any legal liability or responsibility for the accuracy, completeness, or usefulness of any information, apparatus, product, or process disclosed, or represents that its use would not infringe privately owned rights. Reference herein to any specific commercial product, process, or service by trade name, trademark, manufacturer, or otherwise does not necessarily constitute or imply its endorsement, recommendation, or favoring by the United States Government or any agency thereof. The views and opinions of authors expressed herein do not necessarily state or reflect those of the United States Government or any agency thereof. 


\section{ACKNOWLEDGEMENT}

This report was prepared with the support of the U.S. Department of Energy (DOE), Morgantown Energy Technology Center, under Cooperative Agreement Number DE-FC21-93MC30126. However, any opinions, findings, conclusions, or recommendations expressed herein are those of the author(s) and do not necessarily reflect the views of the DOE. 


\section{TABLE OF CONTENTS}

Page

TASK 1.0 OIL AND GAS $\ldots \ldots \ldots \ldots \ldots \ldots \ldots \ldots \ldots \ldots \ldots \ldots \ldots \ldots \ldots \ldots$

Subtask $1.1 \quad$ CROW $^{\mathrm{TM}}$ Process Modeling .................... 1

Subtask 1.3 Development of a Portable Data Acquisition System and Coalbed Methane Simulator ................. 4

Subtask 1.4 Tank Bottom Waste Processing Using the TaBoRR ${ }^{\mathrm{TM}}$ Process ... . 6

TASK 2.0 ADVANCED SYSTEMS APPLICATIONS $\ldots \ldots \ldots \ldots \ldots \ldots \ldots \ldots \ldots$

Subtask 2.1 Development and Optimization of a Process for the Production of a Premium Solid Fuel from Western U.S. Coals .......... 9

Subtask 2.4 Process Support and Development .................. 10

Subtask 2.5 Eastern Shale Oil Residue as an Asphalt Additive . . . . . . . . . . 11

TASK 3.0 ENVIRONMENTAL TECHNOLOGIES $\ldots \ldots \ldots \ldots \ldots \ldots \ldots \ldots$

Subtask 3.1 Solid Waste Management ..................... 13

Subtask 3.2 Remediation of Contaminated Soils ................. 15

Subtask 3.3 The Syn- Ag $^{\text {TM }}$ Process: Coal Combustion Ash Management Option 17

Subtask 3.4 The Maxi-Acid ${ }^{\text {TM }}$ Process: In-Situ Amelioration of Acid Mine Drainage ........................... 18

Subtask 3.5 Spill Test Facility Data Base $\ldots \ldots \ldots \ldots \ldots \ldots \ldots \ldots \ldots \ldots \ldots$

TASK 4.0 APPLIED ENERGY SCIENCE $\ldots \ldots \ldots \ldots \ldots \ldots \ldots \ldots \ldots \ldots \ldots \ldots$

Subtask 4.1 Heavy Oil/Plastics Co-Processing ................. 21

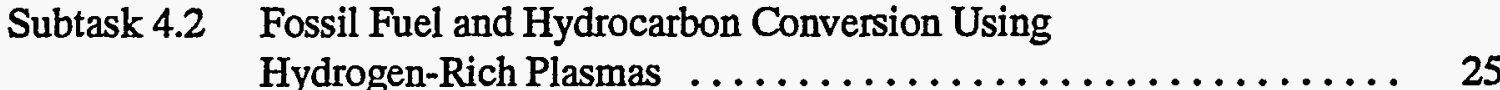

TASK 6.0 REMEDIATION $\ldots \ldots \ldots \ldots \ldots \ldots \ldots \ldots \ldots \ldots \ldots \ldots \ldots \ldots$

Subtask $6.1 \quad$ North Site Remediation .................... 30

CONTRACT STATUS REPORT $\ldots \ldots \ldots \ldots \ldots \ldots \ldots \ldots \ldots \ldots \ldots \ldots \ldots \ldots$

SUBTASK PROJECT SCHEDULE $\ldots \ldots \ldots \ldots \ldots \ldots \ldots \ldots \ldots \ldots \ldots \ldots \ldots$

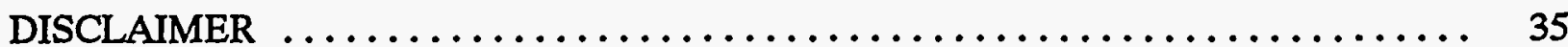




\title{
SUBTASK 1.1
}

\section{CROW $^{\text {TM }}$ PROCESS MODELING}

\author{
Lyle A. Johnson
}

Francis M. Carlson

August - October 1994

\section{OBJECTIVES}

This subtask is to incorporate new physical relationships peculiar to the $C R O W^{\mathrm{TM}}$ process into the existing thermal simulator and to validate the simulator based on controlled laboratory simulations. The activities that have been identified and the specific objectives are:

- development a numerical simulator through the modification of an existing thermal enhanced oil recovery simulator to describe the transport of organic materials in aqueous environments,

- design and conduct physical simulations that will provide data for the verification of the developed numerical simulator,

- perform model verification with the data from the physical simulations, and

- project management and reporting of all efforts including the complete documentation of the numerical simulator.

\section{QUARTER OBJECTIVES}

The objectives for this quarter were to:

- complete the compilation of the data from the two-dimensional tests and the relative permeability testing,
- continue the model verification effort using the results from the test simulations and relative permeability tests, and

- begin documentation of the numerical simulator

\section{ACCOMPLISHMENTS}

- The reactor system was completed and shakedown testing using a brine solution to track the flow paths in the reactor was also completed.

- Testing using three different nonaqueous phase liquids (NAPL) was completed. Tests used a floating or light nonaqueous phase liquid (LNAPL), a sinking or dense nonaqueous phase liquid (DNAPL), and a nonaqueous phase with a density nearly the same as the water (NAPL).

- Relative permeability testing were completed for a LNAPL and a NAPL.

- Model modification was began and is continuing using the data from the twodimensional tests for history matching and verification. 


\section{ACTIVITIES FOR NEXT QUARTER}

- Continue model verification using the results from the two-dimensional simulations and the relative permeability tests.

- Continue documentation of the numerical simulator.

- Begin preparation of the final report for the subtask.

\section{PROCEDURES}

The primary steps being taken in this subtask are:

- model development,

- physical simulations,

- model verification, and

- management and reporting.

Subsubtask 1.1.1 is the modification of an existing thermal enhanced oil recovery simulator to incorporate the phenomena peculiar to the CROW process including but not limited to the inclusion of a convectiondiffusion transport mechanism. This will assist in the ability to describe the transport of organic materials in an aqueous environment. This activity will be used initially to identify the parameters for subsubtask 1.1.2.

Subsubtask 1.1.2 is the conduct of the physical simulations necessary to provide the data for the verification of the numerical simulator developed in subsubtask 1.1.1. The activity includes the development and shakedown of the reactor system deem as the best to provide the required data. Three scenarios of organic contamination in an aquifer are to be investigated: LNAPL contamination floating on groundwater at the top of an aquifer, DNAPL contamination at the bottom of an aquifer, and NAPL contamination that has a density nearly identical to water, resulting in a suspended phase within an aquifer. Also in this activity will be the determination of the relative permeabilities for the organic liquids used in the physical simulations.

Subsubtask 1.1.3 is the verification of the developed numerical simulator using the data produced in subsubtask 1.1.2. Any further modifications of the numerical simulator necessary to history match the produced data will also be done in this activity.

Subsubtask 1.1.4 is the project management required to ensure the proper execution of the subtask and the reporting of the accomplishments. This activity also includes the documentation of the numerical simulator and the inclusion of the documentation into the final task report.

\section{RESULTS}

The CROW model developed during the first year funding extended the existing multiphase, multicomponent, three-dimensional, thermal simulator that was developed for petroleum reservoirs to describe the transport of organic materials in aqueous environments. The model has the ability to describe the fate of organic materials by Arrhenius-type, first order kinetics as well as phase equilibria relationships. These capabilities are necessary to describe the speciation of the oil by bioremediation or steam stripping operations. Because of the models thermal aspects, all reservoir and fluid properties are temperature dependent. the model is also able to perform field simulations for one-, two-, and threedimensions with variable grid spacings, and the use of vertical or horizontal wells. 


\title{
SUBTASK 1.3
}

\section{DEVELOPMENT OF A PORTABLE DATA ACQUISITION SYSTEM AND COALBED METHANE SIMULATOR}

\author{
Francis M. Carlson \\ Charles G. Mones
}

August - October 1994

\section{OBJECTIVES}

The objectives of this subtask are to develop a self-contained, portable data acquisition system, to develop and in-house coalbed methane simulator, and to improve model physics to develop competitive advantage. Therefore, this subtask is divided into three relevant activities:

- Development of Data Acquisition System,

- Development of Coalbed Methane Simulator, and

- Laboratory Work to Improve Model Physics and to Gain Competitive Advantage.

\section{ACCOMPLISHMENTS}

- A decision was made to use Western Research Institute's (WRI) implicit model as a basis for an initial version of the coalbed methane model.

- Formulation of the coalbed methane model has begun.

\section{ACTIVITIES FOR NEXT QUARTER}

- An initial version of the code will be completed addressing primary depletion from coalbed methane reservoirs.
- Comparisons will be made with results from models published in the literature.

\section{PROCEDURES}

Formulation of the coalbed methane simulator is being based on the implicit, multicomponent reservoir simulator previously developed by WRI. The reasons for using the implicit model, at least at this time, are:

- The source code is available and the operation of the model is well understood by WRI engineers involved in the project.

- The construction of the model and the solution technique employed facilitates reformulation into a multicomponent, enhanced coalbed methane simulator. Furthermore, the model is easily extended to explore various approaches to determining equilibrium coefficients.

- The fully implicit nature of the model should promote stable results under conditions of high production/injection rates and high permeability contrasts.

The major limitation of the implicit model, over typically used IMPES models, is the time required to solve the resulting multicomponent equation set. Recognizing this fact, special attention is being given to maintain the number of equations solved to a minimum and a 
determination will be made as whether the implicit approach is usable for field-scale problems. However the ease of reformulating this implicit model to evaluate differing sorption physics recommends its use at this time.

Currently, the formulation envisions the sorption of any number of components with the partitioning between liquid and vapor phases being described by equilibrium relationships given by the extended Langmuir Isotherm Method. Water is a nonvolatile component and is allowed to be produced from the coal cleats according to a gas-water relative permeability curve which is either measured or assumed as a function of saturation in the cleats. Rock compressibility will be accommodated as will swelling of the coal due to sorption. Non-coal (i.e., sandstone) layers will be permitted in the description of the simulation. 


\title{
SUBTASK 1.4
}

\section{TANK BOTTOM WASTE PROCESSING USING THE TABORR ${ }^{\text {TM }}$ PROCESS}

\author{
Robert M. Satchwell
}

August - October 1994

\section{OBJECTIVES}

This subtask is to develop information used for the successful deployment of WRI's patented TaBoRR ${ }^{T M}$ technology. As outlined in the annual project plan, the specific objectives of the proposed work are:

- provide technology support to the field demonstration unit,

- design, construct, and operate a laboratory process demonstration unit (PDU),

- perform numerical modeling for the prediction of the process, and provide an economic analysis of the process, and

- report on all efforts.

\section{QUARTER OBJECTIVES}

The specific objectives for quarter were to:

- analysis tank bottom wastes from a single location,

- model and determine the recovery using the TaBoRR unit with the data obtained from the analysis,

- monitor construction progress of the field demonstration unit, and

- begin the design and construction of the laboratory PDU.

\section{ACCOMPLISHMENTS}

The following accomplishments were completed during this quarter.

- Characterization ofoa tank bottom waste pit was completed. Analyses included basic sediment and water (BS\&W) determination and a distillation curve for the crude oil. The sampled pit was located near Gillette, Wyoming. Analysis indicated that the tank bottom waste was composed of approximately $10 \mathrm{wt} \%$ water, $5 \mathrm{wt} \%$ solids, and 85 wt \% hydrocarbons. Distillation results indicated an initial boiling point of the hydrocarbons was approximately $527^{\circ} \mathrm{F}$ $\left(275^{\circ} \mathrm{C}\right)$.

- Modeling results showed that approximately 25 wt $\%$ of the crude oil could be recovered using the TaBoRR process. This recovery was based on a distillation temperature of $700^{\circ} \mathrm{F}\left(371^{\circ} \mathrm{C}\right)$ at a 1 atmosphere pressure. Based on computed recovery value, this waste pit will not be used as the first site of the field demonstration,

- Construction of the field demonstration unit is $90 \%$ completed. Remaining items to be completed include: the installation of two control valves, the installation of the control and data acquisition systems, and wiring of the unit for power. At the present time, the industrial client has 
postponed the site demonstration of the field unit to the Spring of 1995. The delay is caused by weather constraints and the large amounts of money required for winter operations, and

- Design of the laboratory PDU has been completed. Originally, the PDU was to be designed to be identical to the field unit. However, due to size constraints, scaling criteria, and convenience, electrical heat was implemented in a single feed preheater and the stripper which eliminated the use of counter-current heat exchangers. Another modification included the use of four heated vessels to represent the field stripper unit. This modification would provide a means of simulating the field stripper unit as well a means of determining the fate of contaminants such as sulfur and chloride compounds. At the present time, approximately $40 \%$ of the construction of the laboratory unit has been completed. The laboratory unit is being assembled using modular construction techniques.

\section{ACTIVITIES FOR NEXT QUARTER}

The following activities are scheduled for next quarter.

- Analyze and characterize tank bottom wastes from other locations,

- Monitor progress on the construction of the field demonstration unit, and

- Continue construction of the laboratory PDU.

\section{MAJOR EQUIPMENT LIST}

Data Aquisition and Control System

Hoffman control panel

5 - Honeywell temperature controllers

5 - Omega signal conditoners

American Power Conversion 600watt UPS

24 volt power supply

Assorted terminal strips and fuse blocks

$300 \mathrm{ft}$ Beldon hookup wire

$500 \mathrm{ft}$ Beldon instrument cable

$1000 \mathrm{ft}$ Omega thermocouple wire

Dell 486 computer

Dell VGA monitor

Dell keyboard

Logitech mouse

Labtech control software

Omega analog/ditigal modules

1-CPU card

1-Power supply card

2-Thermocouple input cards

2-Voltage in alalog input cards

21 - type $\mathrm{K} 1 / 4^{\prime \prime}$ thermocouples

24 - thermocouples plugs

1- 0 - 1000psia Omega pressure transducer

5 - 0 - 30 psia Omega pressure transducers

5 - 0 - 10 lb Omega load cells

Toledo, Digitol scale

Brooks, mass flowmeter

6 - indicator lights

GE double pole switch

\section{Electrical Power System}

Hoffman electrical enclosure

5 - Payne, 3-phase power controllers

Square-D breaker and disconnect

\section{Feed System}

55 gallon Stainless Steel Feed tank 1000 psia, 0-2 gpm positive displacement pump

High pressure, sample ball valve

High pressure relief valve

High pressure, check valve 
Preheater System

Chromolox $2.4 \mathrm{~kW}$ heater

Stainless steel shell

Stainless steel 900 psia mating flange

0-1000 psig Marsh pressure gauge

\section{Flash System}

High pressure Whitey adjustable valve

Stainless steel shell

2 - 150 psia Stainless steel mating flanges

2 - 150 psia blind flanges

$1 / 2^{\text {" Stainless Steel Whitey block valves }}$

Liquid accumulators

Sight glass with attachments
Stripper System

4 - Stainless steel shells

4 - 150 psia Stainless steel mating flanges

4 - $1.6 \mathrm{~kW}$ Chromolax heaters

4 - Liquid accumulators

4 - Sight glasses with attachments

Sweep gas manifold

4 - Sweep gas rotameters

4 - 1/4" Sweep gas check valves

4 - 1/2" Stainless Steel Whitey block valves

\section{Condenser System}

Neslab CFT-300 Refrigerated Recirculator

5 - Young refluxing condensers

7 - 3/8" WOG brass valves

2 - 3/4" WOG brass valves 
SUBTASK 2.1

\section{DEVELOPMENT AND OPTIMIZATION OF A PROCESS FOR THE PRODUCTION OF A PREMIUM SOLID FUEL FROM WESTERN U.S. COALS}

Norm Merriam

August - October 1994

\section{OBJECTIVES}

The long-term objective of this subtask is to develop a technically and economically feasible process for producing a low-sulfur, high-Btu, fuel from western coals. The objectives for 1993 were:

- to develop an economical method to control spontaneous combustion in pyrolyzed coal, and
- to demonstrate the removal of mercury from the coal by thermal treatment.

The objective for the work in 1994 is to test the process using a continuous, bench-scale system that integrates the drying and pyrolysis reactors.

\section{QUARTER OBJECTIVES}

No activities were planned for this quarter. 


\section{SUBTASK 2.4}

PROCESS SUPPORT AND DEVELOPMENT

David Sheesley

August - October 1994

\section{OBJECTIVE}

The objective of this subtask is to obtain support leading to development of a COMPCOAL ${ }^{\text {TM }}$ pilot plant.

\section{QUARTER OBJECTIVE}

The objective for this quarter was to prepare the topical report of the results of this study.

\section{ACCOMPLISHMENTS}

Work continued on the preparation of the topical report.

\section{PROCEDURES}

The COMPCOAL process consists of four steps:

- Initial Drying

- Partial Decarboxylation

- Mild Pyrolysis

- Stabilization

\section{RESULTS}

The process reduces the weight of coal by about $40 \%$, thus reducing transportation costs and improving coal marketability. Companion projects with this process have produced stabilized coal particles resistant to oxidation and readsorption of moisture.

\section{ACTIVITIES FOR NEXT QUARTER}

The topical report, including the presentation materials will be completed. 


\title{
SUBTASK 2.5
}

\section{EASTERN SHALE OIL RESIDUE AS AN ASPHALT ADDITIVE}

\author{
Ken Thomas \\ Mike Harnsberger
}

August - October 1994

\section{OBJECTIVES}

The objectives of this subtask are to determine whether an asphalt modifier produced from eastern shale oil is or is not beneficial to 1) reduce age hardening and 2) reduce moisture damage susceptibility in conventional asphalt concrete used in public roads. Several activities have been identified. The specific objectives are as follows.

- Preparation of an experimental plan

- Acquisition and preparation of an eastern shale oil residue suitable for evaluation

- Preparation of a sample matrix that will be the subject of testing and evaluation

- Testing and evaluation of samples that have been subjected to aging tests

- Testing and evaluation of samples that have been subjected to successive freezethaw cycling

- Preparation of a topical report which discusses the results obtained and the conclusions drawn

\section{QUARTER OBJECTIVES}

The objectives for this quarter were to:

- complete the preparation of an eastern shale oil sample suitable for testing, and
- prepare the sample matrix that would be the subject of testing

\section{ACCOMPLISHMENTS}

- An eastern shale oil sample suitable for testing was prepared by vacuum distilling the original sample to produce a residue that met the requirements of an AC-2.5 asphalt.

\section{ACTIVITIES FOR NEXT QUARTER}

- Prepare the sample matrix that will be the subject of testing

- Begin the aging and freeze-thaw cycling tests

\section{PROCEDURES}

The original eastern shale oil sample was vacuum distilled in an all-glass still to produce a sample suitable for testing. During the distillation, the pot and the overhead temperatures were monitored with chromelalumel thermocouples, and the pressure was monitored with a Datametrics barocel. The viscosity at $60^{\circ} \mathrm{C}\left(140^{\circ} \mathrm{F}\right)$ of the resulting residue was determined using a Brookfield viscometer (ASTM Method D 4402). 


\section{RESULTS}

Approximately 1000 grams of eastern shale oil which was sent to WRI by the Center for Applied Energy Research at the University of Kentucky was vacuum distilled to produce a residue that has been submitted for the determination of viscosity at $60^{\circ} \mathrm{C}\left(140^{\circ} \mathrm{F}\right)$. The viscosity of the original sample, as reported last quarter, was $1.3 \mathrm{~Pa} \cdot \mathrm{S}(13 \mathrm{P})$ at $60^{\circ} \mathrm{C}\left(140^{\circ} \mathrm{F}\right)$. This sample was deemed to be too fluid for use as an asphalt additive, thus, the necessity for the vacuum distillation.
The final pot and overhead temperatures during the distillation were, respectively, $242^{\circ} \mathrm{C}\left(468^{\circ} \mathrm{F}\right)$ and $174^{\circ} \mathrm{C}\left(345^{\circ} \mathrm{F}\right)$ at 110 $\mathrm{mm}$ of mercury. Corrected to atmospheric pressure this corresponds to an overhead temperature of $250^{\circ} \mathrm{C}\left(482^{\circ} \mathrm{F}\right)$. Ninety five milliliters of distillate were removed from the original sample during the vacuum distillation process. The viscosity of the residue at $60^{\circ} \mathrm{C}$ $\left(140^{\circ} \mathrm{F}\right)$ is $23.9 \mathrm{~Pa} \cdot \mathrm{S}(239 \mathrm{P})$. This satisfies the requirements of an AC-2.5 asphalt which was the goal of the distillation. 


\title{
SUBTASK 3.1
}

\section{SOLID WASTE MANAGEMENT}

\author{
Alan E. Bland \\ Terry H. Brown
}

August - October 1994

\section{OBJECTIVES}

Project objectives are to develop the fundamental data and technologies by which industry can assess and implement economical and technically viable ash management strategies and plans for CCT ashes.

\section{QUARTERLY OBJECTIVES}

The objectives for the quarter were to:

- continue chemical and physical characterization of ashes from coal-fired and coal/coke-fired FBC facilities,

- continue the analytical methods development and the synthesis of ettringite and thaumasite minerals, and

- continue the assessment of methods to control hydration reactions.

\section{ACCOMPLISHMENTS}

- A number of FBC facilities have been contacted and have agreed to supply ash for the geotechnical, conditioning and chemical hydration reaction testing. These include: low-sulfur and ash bituminous coal fired, petroleum coke fired, low-sulfur subbituminous, high-sulfur coal and petroleum coke fired, and high-sulfur coal fired PFBC. To date two ashes have been collected and chemical/physical characterization has been initiated.
- Processing options for these types of materials have been defined and disclosures written.

- Ettringite of variable composition have been synthesized and analyzed by a number of analytical techniques. These techniques include XRD, TGA and DTGA, SEM and DSC.

- An additional activity was initiated with Montana-Dakota Utilities. The activity is designed to examine the technical feasibility of producing a Controlled LowStrength Flowable Fill Material (CLSFFM) from FBC ash.

\section{ACTIVITIES FOR NEXT QUARTER}

- Continue acquisition, testing and characterization of ashes from FBC facilities.

- Continue the analytical methods development and the synthesis of ettringite and thaumasite minerals.

- Continue assessment of the processing options.

- Continue the mix design study of FBC ash based CLSFFM. 


\section{PROCEDURES}

Standard ASTM procedures for the geotechnical testing are to be used, including ASTM D-698 and 1557 for moisture-density relationship, ASTM C-109 (modified) for unconfined compressive strength, and ASTM C-157 for dimensional stability (expansion/ shrinkage) testing. Chemical characterization used ASTM wet chemical methods, as well as standard ICAP, XRF, TGA, DSC, SEM and $\mathrm{XRD}$ techniques.

\section{RESULTS}

The following activities were conducted during the reporting period.

A number of FBC facilities have been contacted and have agreed to supply ash for the geotechnical, conditioning and hydration reaction testing. These include: low sulfur and ash bituminous coal-fired, petroleum coke fired, low-sulfur subbituminous coal-fired, high-sulfur coal and petroleum coke-fired, and high-sulfur coal fired PFBC. To date, ashes from two facilities have been received. Initial chemical and physical characterization of the ashes is underway.

In addition to the chemical/physical properties of the ashes, the standard geotechnical properties of the ashes are being determined. These include, moisture-density relationships (Proctors), unconfined compressive strength, and dimensional stability.

Central to the issue of CCT ash hydration reactions and product stability is the availability of methods for the identification and/or quantification of the appropriate hydration phases (portlandite, gypsum, ettringite/thaumasite). Ettringite of variable composition has been synthesized and analyzed by a number of analytical techniques. These techniques include XRD, TGA and DTGA, DSC and SEM. A number of ettringites have been synthesized and analyzed by the above methods.
WRI/DOE and Montana Dakota utilities have entered into a jointly funded project to examine the technical feasibility of producing Controlled Low-Strength Flowable Fill Material (CLSFFM) from CFBC ash from the Heskitt plant in North Dakota. CLSFFM is a material composed of low amounts of cement, Class $\mathrm{F}$ or $\mathrm{C}$ fly ash, fine aggregate and water. CLSFFM is not concrete and is in a flowable state at time of placement. CLSFFM is usually mixed in a ready mix truck, keeping the material mixing during transport to prevent segregation of the aggregate. The CLSFFM can be discharged by either chutes or can be pumped using standard concrete or grouting equipment. A number of construction related applications have been documented for the use of conventional CLSFFM, including:

- removable backfills

- structural fills

- isolation fills

- trench bedding

- road base

- floor base

- void fills

- caisson and pipe fills

- small bridge restorations

Preliminary mix design of CLSFFM using the CFBC ash from the MDU Heskitt plant in Mandan, North Dakota were conducted.

Other data is considered confidential and proprietary to WRI. This confidential and proprietary data will be discussed with COTR and will be included in a confidential topical report at a later date. 


\section{SUBTASK 3.2}

\section{REMEDIATION OF CONTAMINATED SOILS}

Terry H. Brown

August - October 1994

\section{OBJECTIVES}

The primary objective of this subtask is to develop physical and chemical treatments to remove inorganic and organic toxins from contaminated materials. The project is divided into four activities:

- the acquisition of equipment and materials for the construction of the soil washing systems to be used in the remediation tests;

- the preliminary evaluation of washing and remediation techniques for materials contaminated with metals and hydrocarbons;

- the determination of physical and chemical treatment options for remediating mercury contaminated soils associated with oil and gas pipeline locations; and

- technical project management and reporting.

\section{QUARTER OBJECTIVES}

The objectives for this quarter were:

- characterization of the mercury contaminated soil materials, and

- conduct preliminary attrition scrubber testing of the contaminated materials using various combinations of reagents.

\section{ACCOMPLISHMENTS}

- the contaminated samples were size fractionated using wet and dry sieving methods; and

- the mercury levels present in each size fraction were determined.

\section{ACTIVITIES FOR NEXT QUARTER}

- the safety program specifically oriented to the remediation of mercury contaminated soils will be finalized and the necessary health and safety equipment will be purchased prior to the initiation of the testing program and;

- the preliminary attrition scrubber testing of the contaminated materials using combinations of reagents will be initiated.

\section{PROCEDURES}

The procedures used to do the work accomplished during this quarter included:

- wet sieved particle size separations were done using a "Wet-Vac" wet screening system that operates with continuous water flow, vibration, and vacuum;

- dry sieve particle size separations were done using a "Ro-Tap" vibrating, sieve system; and 
- the mercury analysis was accomplished using a mercury vapor atomic absorption unit.

\section{RESULTS}

The levels of mercury associated with the various size fractions of materials has been completed. As expected, the -200 mesh material contains about $86 \%$ of the mercury contaminant on a wet sieve basis and about $76 \%$ on a dry-sieve basis.
Prior to the initiation of the work plan for the attrition scrubbing evaluations, a complete health and safety plan is being developed.

Confidential data will be discussed with the project monitor and a confidential topical report will be written at a latter date. 


\title{
SUBTASK 3.3
}

\section{THE SYN-AGTM PROCESS: COAL COMBUSTION ASH MANAGEMENT OPTION}

\author{
Alan E. Bland
}

August - October, 1994

\section{OBJECTIVES}

Project objectives are to develop and demonstrate the technical process feasibility and economic viability of the Syn- $\mathrm{Ag}^{\mathrm{TM}}$ process for power plant ashes, including 'offspec' ashes. The specific objectives are:

- develop and document the use of a range of ashes for the Syn-Ag process;

- determine the optimum processing conditions for the Syn-Ag process;

- verify the properties of the aggregate produced from the Syn-Ag process; and

- determine the process costs including capital and operating costs for the Syn-Ag process.

\section{QUARTERLY OBJECTIVES}

The objectives for the quarter were:

- conduct pelletizing tests, and

- evaluate the Syn-Ag properties as a function of ash sources.

\section{ACCOMPLISHMENTS}

- Disclosures have been written and patent applications are being considered. Copies of the disclosures have been supplied to the DOE Patent Office. As a result, all information about the Syn-Ag process remains confidential to WRI and protected therein. Confidential data will be discussed with project monitors and will be included in a confidential topical report at a later date.

- Additional ash material has been obtained from two coal fired western U.S. facilities and evaluated in the Syn-Ag process.

\section{PROCEDURES}

Standard ASTM procedures for the geotechnical testing were used, including ASTM D-698 and 1557 for moisture-density relationship, ASTM C-109 (modified) for unconfined compressive strength, and ASTM C-157 for dimensional stability (expansion/shrinkage) testing. Chemical characterization used ASTM wet chemical methods, as well as standard ICAP, XRF and $\mathrm{XRD}$ techniques.

\section{ACTIVITIES FOR NEXT QUARTER}

- Conduct additional process and product testing of the Syn-Ag process.

\section{RESULTS}

The testing results are considered proprietary and confidential to WRI. Disclosures have been written on the Syn-Ag process and patent applications are intended to be filed. The confidential data will be discussed with COTR and will be included in a confidential topical report at a later date. 
SUBTASK 3.4

\title{
THE MAXI-ACID ${ }^{\text {TM }}$ PROCESS: IN-SITU AMELIORATION OF ACID MINE DRAINAGE
}

\author{
Terry H. Brown
}

August - October 1994

\section{OBJECTIVES}

The objective of this subtask is to develop a method for the in-situ amelioration of acid mine drainage problems. The overall subtask will be done in three activities:

- the laboratory simulation and method development;

- the design and modeling of the processes including the containment system; and

- the application of the technology in a field trial.

\section{QUARTER OBJECTIVES}

The objectives for this quarter were:

- completion of the detailed work plan; and

- initiation of the laboratory investigations.

\section{ACCOMPLISHMENTS}

The work accomplished includes:

- characterization of soil materials collected in east Texas that contains large quantities of potential acidity;

- preliminary evaluations of the acid generating capabilities of materials containing high levels of potential acidity (pyritic materials) using humidity cells; and
- the impact of oxidizers on soil materials that contain high levels of potential acidity in unconfined columns and in confined flexible-walled permeameter.

\section{ACTIVITIES FOR NEXT QUARTER}

- continue evaluations of the influence of environmental conditions on acid and alkalinity production.

- the leaching pad will be designed and constructed.

\section{PROCEDURES}

The procedures used to do the work accomplished during this quarter included:

- weathering evaluations were made using Plexiglas and flexible-walled permeameters

\section{RESULTS}

The work accomplished includes: characterization of soil materials collected in east Texas that contains large quantities of potential acidity; (2) preliminary evaluations of the acid generating capabilities of materials containing high levels of potential acidity (pyritic materials) using humidity cells; (3) the impact of oxidizers on soil materials that contain high levels of potential acidity in unconfined columns and in confined flexiblewalled permeameters. 
The materials used for work done under activity 1 were collected from the lignite mining area of southeastern Texas. The materials collected consisted of an overburden material that had been influenced by air oxidation for a considerable period of time and a reduced material that had recently been extracted from the overburden formation. The oxidized material had a $\mathrm{pH}$ of 2.8 and an acid/base potential of -30.4 tonnes $\mathrm{CaCO}_{3} / 1000$ tonnes of overburden material, and the reduced material had a $\mathrm{pH}$ of 4.1 and an acid/base potential of -58.3 tonnes $\mathrm{CaCO}_{3} / 1000$ tonnes of overburden material.

The oxidized material contains significant salt levels $(E C=9.5)$ compared to the unoxidized material which has an $E C=2.6$. This difference would be expected as a result of pyrite oxidation and the subsequent release of elements.
The acid generating capacity of the acid forming materials are currently being evaluated using a humidity cell technique. The intention of this work is to provide a baseline for our continued effort with Maxi-Acid. The acidforming materials used in this study had an initial $\mathrm{pH}$ of 3.44 and an EC of $3.24 \mathrm{mhos} / \mathrm{cm}$. Following 14-days of humidity cell weathering the average $\mathrm{pH}$ was 2.85 and the EC was 6.62 . These data show pyrite oxidation is occurring at a relatively high rate.

Confidential data will be discussed with the project monitor and a confidential topical report will be written at a latter date. 


\title{
SUBTASK 3.5
}

\section{SPILL TEST FACILITY DATA BASE}

\author{
David Sheesley
}

August - October 1994

\section{OBJECTIVES}

The objective of this subtask is gather data and references related to chemical spill research and make them available to the Department of Energy (DOE), the Environmental Protection Agency (EPA), Desert Research Institute (DRI), the Department of Transportation (DOT), and other stakeholders in the research. This subtask includes the following activities:

- convert the data acquired at the DOE Liquefied Gaseous Fuels Spill Test Facility (LGFSTF) into a uniform, understandable format;

- compile a subject-indexed bibliography of spill related research;

- compile a mailing list parties interested in spill research.

\section{QUARTER OBJECTIVES}

The objectives for this quarter were to:

- finish the conversion of post-1988 data collected at the LGFSTF,

- add entries to the bibliography using computerized search facilities and references found in the literature,

- compile a preliminary version of the mailing list.

\section{ACCOMPLISHMENTS}

- The conversion of the post-1988 data collected at the LGFSTF has been completed.

- About 1700 entries have been added to the bibliography since the beginning of this subtask. Additionally, keywords have been added and a QA/QC check of the entries has been completed. More entries are added every week.

- The preliminary version of the mailing list has been compiled.

\section{ACTIVITIES FOR NEXT QUARTER}

- Begin the conversion of pre-1988 data collected at the LGFSTF

- Acquire test plans, key contact names, and other relevant documentation for post1988 data collected at the LGFSTF

- Continue adding and verifying entries to the bibliography using computerized search facilities and references found in the literature

- Begin verification of the mailing list 


\title{
SUBTASK 4.1
}

\section{HEAVY OIL/PLASTICS CO-PROCESSING}

\author{
Frank D. Guffey
}

August - October 1994

\section{OBJECTIVE}

The objective of this research is to evaluate the activity responsible for the decrease in thermal decomposition temperature observed when a mixture of plastic resin types are co-processed with heavy oil. Three activities are defined with the following specific objectives:

- identify the active agent responsible for the observed decrease in thermal decomposition temperature,

- determine the sensitivity of the active agent,

- propose a mechanism to explain the activity of the active agent.

\section{QUARTER OBJECTIVES}

The objectives of this quarter were to:

- complete evaluation of the experimental data and propose a mechanism of activity to explain the observed decrease in thermal decomposition temperature,

- begin preparation of a final report.

\section{ACCOMPLISHMENTS}

- A mechanism to explain the decrease in thermal decomposition temperature that is observed when a mixture of waste plastics are processed with a heavy oil has been completed.

- Drafts have been completed for the Introduction, the Experimental and part of the Results and Discussion Sections of the final report.

\section{ACTIVITIES FOR NEXT QUARTER}

- Complete and submit the final report.

\section{PROCEDURES}

- Evaluation of data and calculation of results.

- Search of literature for related references.

\section{RESULTS}

The mechanism proposed to explain the thermal decomposition of waste plastics at lower than expected temperatures is a free radical induced chain depolymerization reaction. The importance of free radicals in the thermal decomposition has been discussed with respect to liquefaction of coal and waste tires (Ibrahim and Seehra 1993). In addition, the application of free radical initiators to promote processes based on free radical mechanisms has been reported (Scott 1972). 
In the proposed mechanism, free radicals liberated from an initiator such as polyvinyl chloride (PVC) at temperatures below $400^{\circ} \mathrm{C}$ act to start the process. In the reaction media, free radicals from the initiator attack the polymer structures to satisfy their electronic structures. This results in the abstraction of a proton from the polymer molecule which initiates the free radical process to decompose the polymer of the structure. Once a radical is formed in the polymeric structure, the polymer "unzips" through fragmentation reactions followed by rearrangements of the fragments to produce stable cyclic and olefinic species. The result is decomposition of the plastics at temperatures lower than expected, yielding products that are low molecular weight hydrocarbons.

The effect of the free radical initiator can be observed by comparison of results from several experiments performed at different temperatures with the addition of PVC with similar results where PVC was not used. These experiments were performed in the batch reactor using a mixture of waste high and low density polyethylene, polypropylene, and polystyrene, and SAE 50 weight oil as the heavy oil. The results summarized in Table 1 compare results from three experiments performed at different temperatures in the presence of PVC with results from an experiment performed without the addition of PVC. The residence time, heavy oil/plastics mass ratio, and type of oil were held constant during these experiments. The conditions were not optimized for maximum distillate yield.
The results presented in Table 1 are the plastics conversion based on the mass of plastic charged to the reactor and the mass of plastic recovered at the end of the experiment, and the total conversion is the weight percentage of distillate produced based on the combined charge of waste plastic and SAE 50 weight motor oil. Both the plastics conversion and the total conversion increase as the temperature increases as would be expected based on the increase in the available energy at the higher temperatures.

Of more interest is comparison of these results with the results from the experiment where PVC was not added to the reaction at $380^{\circ} \mathrm{C}$ $\left(716^{\circ} \mathrm{F}\right)$. The plastics conversion without the addition of PVC was only $19.8 \%$ as compared with $27.9 \%$ with the addition of PVC. This is a $41 \%$ increase in plastics conversion with the addition of PVC. A similar trend in the increase in the total conversion to distillate is observed with the use of the free radical initiator.

There also appears to be a synergistic effect between the waste plastic and the heavy oil in the presence of a free radical initiator. Two experiments were performed at $390^{\circ} \mathrm{C}$ $\left(734^{\circ} \mathrm{F}\right)$, one of the experiments did not use the plastics charge, and was designed to determine the distillate yield from the oil. The second experiments was performed in the normal manner with the plastic and heavy oil charge. The results from these two experiments are listed in Table 2.

Table 1. Comparison of Plastics Conversion and Distillate Yields from Experiments Using PVC with Results from an Experiment not Using PVC

Parameter

\begin{tabular}{lcccc} 
Temperature $\left({ }^{\circ} \mathrm{C}\right)$ & 370 & 380 & 390 & 380 \\
Initiator (PVC) & Yes & Yes & Yes & No \\
\hline & & & & \\
Plastics Conversion (\%) & 24.6 & 27.9 & 30.5 & 19.8 \\
Total Conversion (\%) & 7.7 & 14.0 & 27.0 & 10.0 \\
\hline
\end{tabular}




\begin{tabular}{|c|c|c|c|}
\hline $\begin{array}{l}\text { Plastics Used } \\
\text { Result }\end{array}$ & $\begin{array}{c}\text { No } \\
\text { Expt. }\end{array}$ & $\begin{array}{l}\text { Yes } \\
\text { Expt. }\end{array}$ & $\begin{array}{c}- \\
\text { Theo. }\end{array}$ \\
\hline $\begin{array}{l}\text { Plastics Conversion (\%) } \\
\text { Total Conversion (\%) }\end{array}$ & - & $\begin{array}{l}30.5 \\
27.0\end{array}$ & - \\
\hline
\end{tabular}

The total conversion to distillate for these experiments are $11.5 \%$ without plastics, and $27.0 \%$ with both plastics and oil. Based on the total conversion (11.5\%) from the experiment not using plastics and the plastics conversion for the experiment using plastics (30.5\%), a theoretical total recovery can be calculated. The theoretical conversion is calculated to be 13.1\%. This value is significantly lower than the experimental conversion of $27.0 \%$. These results indicate that there is a synergistic effect. Apparently the free radical induced decomposition of the plastics enhances decomposition of the oil. This may have additional economic importance in processing of heavy oils.

The type of oil used in the process also has an effect on the plastics conversion. A summary of the results from two experiments conducted with two different types of heavy oils are listed in Table 3. The temperature, residence time, and the heavy oil/plastics mass ratio were held constant between these two experiments.
Plastics conversion increased from $30.5 \%$ when SAE 50 weight oil was used to $75.9 \%$ when the heavy oil was fluidized catalytic cracker heavy recycle oil (FCC). The SAE 50 weight oil is composed of compounds that contain a high percentage of cyclic saturated compounds and alkyl substituents. These types of compounds are relatively reactive to free radical processes and will undergo decomposition in this process and produce a significant amount of distillate. In this process they will also interact with the free radical initiator and free radicals formed in the polymer chains. The reactions of the heavy oil in these free radical processes decreases the conversion of plastics by acting as scavengers for the free radical initiators and providing termination reactions for free radicals in the polymer chains.

The FCC heavy recycle oil has been thermally stressed in the FCC process resulting in an oil the is essentially devoid of cyclic saturate structures and alkyl substituents. This type of

Table 3. Comparison of Plastic Conversion from Two Experiments Using Different Heavy Oils

Parameter

\begin{tabular}{lcc}
\hline & 390 & 390 \\
Temperature $\left({ }^{\circ} \mathrm{C}\right)$ & FCC & SAE 50 \\
Heavy Oil & & \\
\hline & 75.9 & 30.5 \\
\hline
\end{tabular}


oil does not act as a scavenger for the free radical initiator or as a termination reactant in the depolymerization of the plastic. This results in increased conversion of the plastics with the FCC oil as compared to the experiments using SAE 50 weight oil. In addition, experiments using only the FCC oil, measurable quantities of distillate were not produced up to temperatures of $450^{\circ} \mathrm{C}$ $\left(842^{\circ} \mathrm{F}\right)$. This supports the discussion that the FCC oil does not appreciably interact with the free radical initiator to produce distillate.

\section{REFERENCES}

Ibrahim, M.M. and M.S. Seehra, 1993, Thermogravimetric and Free Radical Evidence for Improved Liquefaction of Coal with Waste Tires, American Chemical Society, Preprints, Division of Fuel Chemistry, 38 (3), 841-847.

Scott, Charles E., 1972, Waste Rubber Disposal, United States Patent, 3,700,615. 


\title{
SUBTASK 4.2
}

\section{FOSSIL FUEL AND HYDROCARBON CONVERSION USING HYDROGEN-RICH PLASMAS}

\author{
Francis P. Miknis \\ Will Grimes
}

August - October 1994

\section{OBJECTIVES}

The objective of this subtask is to develop a novel and innovative, noncatalytic method for directly converting fossil fuel materials to hydrogen-rich fuels while simultaneously reducing the heteroatom contents.

\section{QUARTER OBJECTIVES}

Continue microwave plasma experiments using methane.

\section{ACCOMPLISHMENTS}

- A reactor system that continuously circulates liquids in the microwave plasma has been built and tested.

- Crude oil has been irradiated using hydrogen and methane plasmas.

- Simulated distillations have been obtained on the irradiated materials.

\section{ACTIVITIES FOR NEXT QUARTER}

Continue methane and hydrogen plasmas experiments on petroleum resids.

\section{PROCEDURES}

Fossil fuel hydrocarbon materials are exposed to microwave-generated plasmas to produce improved hydrogen-rich liquid fuels. Experiments are conducted on heavy crude oils and resids with plasmas generated from hydrogen and methane. Experiments are conducted in a pressure range of $0-1333 \mathrm{~Pa}$ $(0-10$ torr), flow rates of $0-10 \mathrm{cc} / \mathrm{min}$, and variable microwave power up to $7.2 \times 10^{5}$ joules (200 watts). Produced and distilled liquids are trapped in a dry ice/methanol bath; gases are analyzed by gas chromatography (GC). Simulated distillations, and gas chromatography/mass spectrometry (GC/MS) and nuclear magnetic resonance (NMR) analyses are made on the liquid products from selected experiments to determine the extent of hydrogenation, methanation and heteroatom removal that results from exposure to different plasmas under various conditions.

\section{RESULTS}

During the quarter a quartz reactor system that continuously circulates liquids was designed, built and tested (Figure 1). The purpose of circulating the liquids is to provide a fresh surface to the reactive species which are generated inside the microwave cavity. The circulating liquids can be positioned in the microwave cavity or at a given distance outside the cavity. 


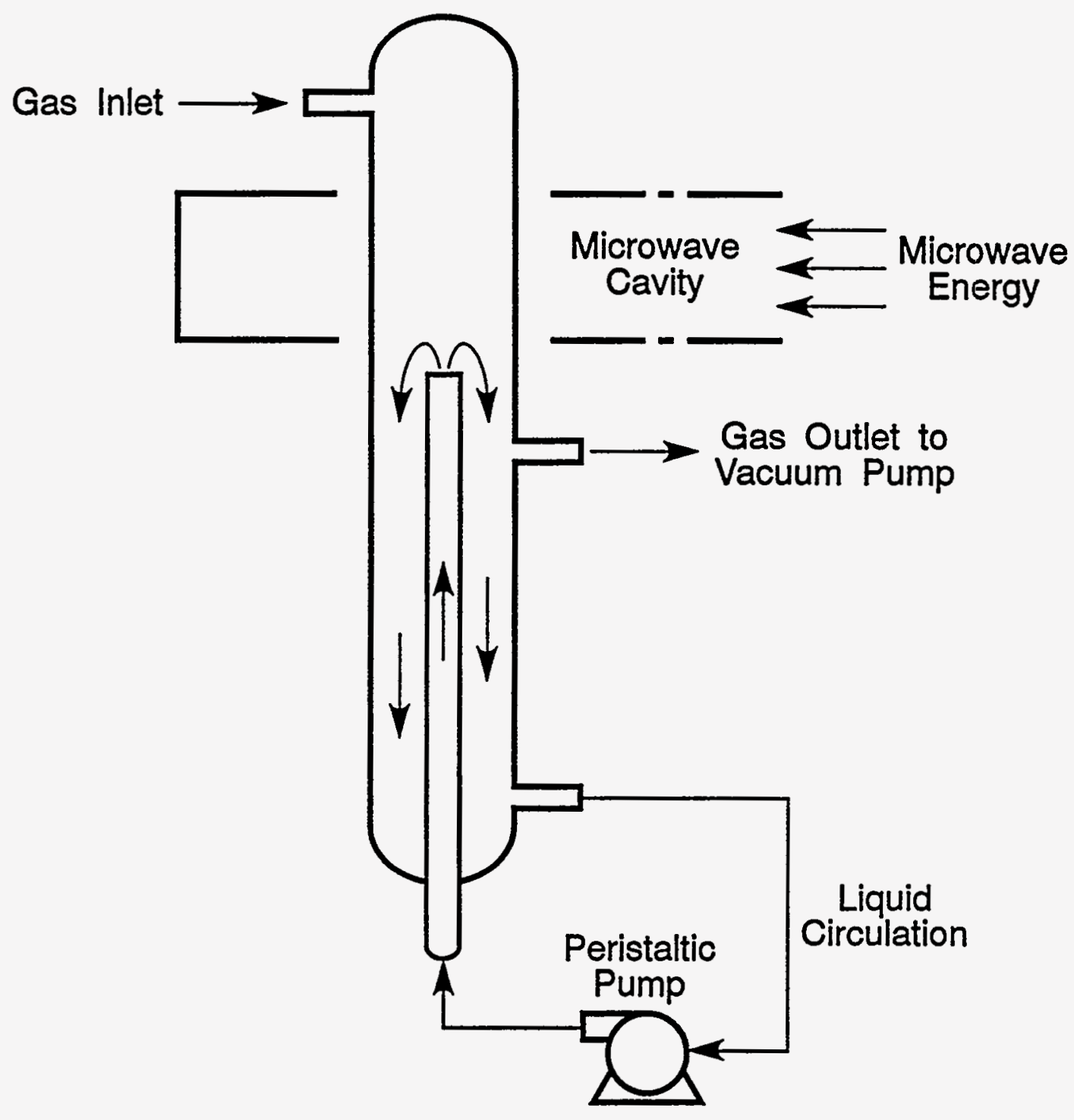

Figure 1. Schematic Diagram of Continuous Flow Quartz Reactor System

Microwave plasma experiments were conducted on an unrefined crude oil to test the circulating reactor system. Experiments were conducted for different periods of time using hydrogen and methane plasmas, at pressures of $\sim 667 \mathrm{~Pa}(\sim 5$ torr), flow rates of $5 \mathrm{cc} / \mathrm{min}$ and $7.2 \times 10^{5}$ joules (200 watts) of microwave power (Table 1).

A certain portion of the stating material was distillable was under the low pressure at which the plasma experiments were conducted. As a result, some distillate material was collected in the dry ice/methanol trap when the microwave generator was off and when there was no hydrogen or methane in the plasma. Run 86554 (Table 1) represents a blank run when the microwaves were turned off and there was no plasma, and run 865-60 represents a blank in which the there was microwave power in the cavity and a helium plasma was generated. Runs 865-56 and 856-64 represent runs when hydrogen and methane were added to the plasma, respectively. 
Table 1. Summary of Microwave Plasma Experiments on Crude Oil

\begin{tabular}{ccccccc}
\hline Sample & $\begin{array}{c}\text { Pressure, } \\
\mathrm{Pa} \text { (torr) }\end{array}$ & Gas & $\begin{array}{c}\text { Flow, } \\
\text { cc/min }\end{array}$ & $\begin{array}{c}\text { Microwave } \\
\text { Power, } \\
\text { joules (watts) }\end{array}$ & $\begin{array}{c}\text { Temperature, } \\
{ }^{\circ} \mathrm{C}\left({ }^{\circ} \mathrm{F}\right)\end{array}$ & $\begin{array}{c}\text { Reaction Duration, } \\
\text { minutes }\end{array}$ \\
\hline $865-50$ & $1012(7.6)$ & $\mathrm{He} / \mathrm{H} 2$ & $5 / 5$ & $7.2 \times 10^{5}(200)$ & $\begin{array}{c}38.9-58.9 \\
(102-138)\end{array}$ & 98 \\
$865-52$ & $1012(7.6)$ & $\mathrm{He} / \mathrm{H} 2$ & $5 / 5$ & $7.2 \times 10^{5}(200)$ & $\begin{array}{c}38.9-58.9 \\
(102-138)\end{array}$ & 98 \\
$865-54$ & $733(5.5)$ & $\mathrm{He}$ & 5 & $0(0)$ & $\begin{array}{c}38.3-49.4 \\
(101-121)\end{array}$ & 287 \\
$865-56$ & $733(5.5)$ & $\mathrm{He} / \mathrm{H} 2$ & $5 / 5$ & $7.2 \times 10^{5}(200)$ & $\begin{array}{c}44.4-71.7 \\
(112-161)\end{array}$ & 180 \\
$865-60$ & $613(4.6)$ & $\mathrm{He}$ & 5 & $7.2 \times 10^{5}(200)$ & $57.8(136)$ & 75 \\
$865-62$ & $547(4.1)$ & $\mathrm{He}$ & 5 & $7.2 \times 10^{5}(200)$ & $\begin{array}{c}33.9-65.6 \\
(93-150)\end{array}$ & 60 \\
$865-64$ & $747(5.6)$ & $\mathrm{He} / \mathrm{CH} 4$ & $5 / 5$ & $3.6-5.4 \times 10^{5}$ & $43.3-70.6$ & 260 \\
\hline
\end{tabular}

The distillate and resid from these runs were collected and simulated distillations were performed to obtain an assessment of the quality of the liquids. The results for the distillates are shown in Figure 2. The data indicate that up to the temperature at which about 50 vol \% of the liquid product is distilled, the boiling temperatures of the plasma produced distillates are lower than the distillate fraction of the crude oil produced in the absence of the plasma. A bar graph comparing the initial boiling points for the four distillate fractions are shown in Figure 3. The distillates collected from exposure to hydrogen and methane plasmas had initial boiling points lower than the materials generated during the blank runs. The distillate from the crude oil in the absence of any plasma had the highest initial boiling point. These data suggest that some improvement of distillate quality may have been obtained during irradiation of the crude oil in the hydrogen and methane plasmas. However, material balances were not obtained so that the results could not be quantitated.
During experiments on the generation of plasmas from methane, some liquids were produced and collected in the dry ice/methanol trap. It was estimated that between 5 and $10 \%$ of the methane was converted to liquids from recombination reactions of the reactive radical and ion species in $t$ plasma. GC/MS and ${ }^{1} \mathrm{HNMR}$ analyses was made on the liquid product. The GC/MS analyses identified a wide variety of unsaturated compounds including, benzene, toluene, ethyl benzene, methyl and ethyl naphthalenes, and small amounts of larger aromatic rings. $A{ }^{1} \mathrm{H}$ NMR spectrum of the liquid product is shown in Figure 4. The spectrum clearly shows a large number of aliphatic hydrogens ( $0-4 \mathrm{ppm})$ and aromatic hydrogens (6-8 ppm) in the sample. Olefinic hydrogens ( $4-6 \mathrm{ppm}$ ) represent a small amount of the total hydrogen composition of the sample. 


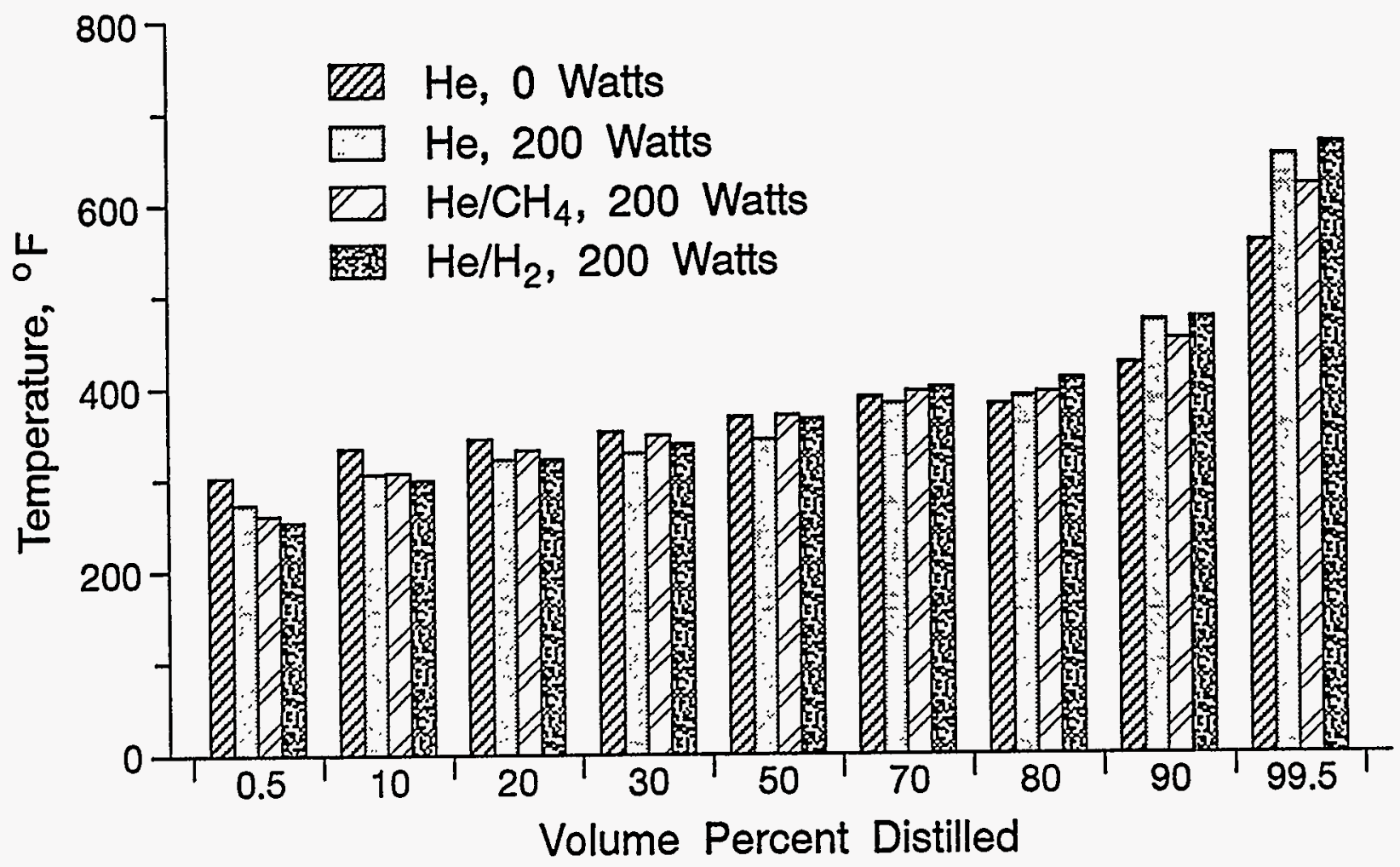

Figure 2. Simulated Distillation Curves for Plasma Produced Distillates

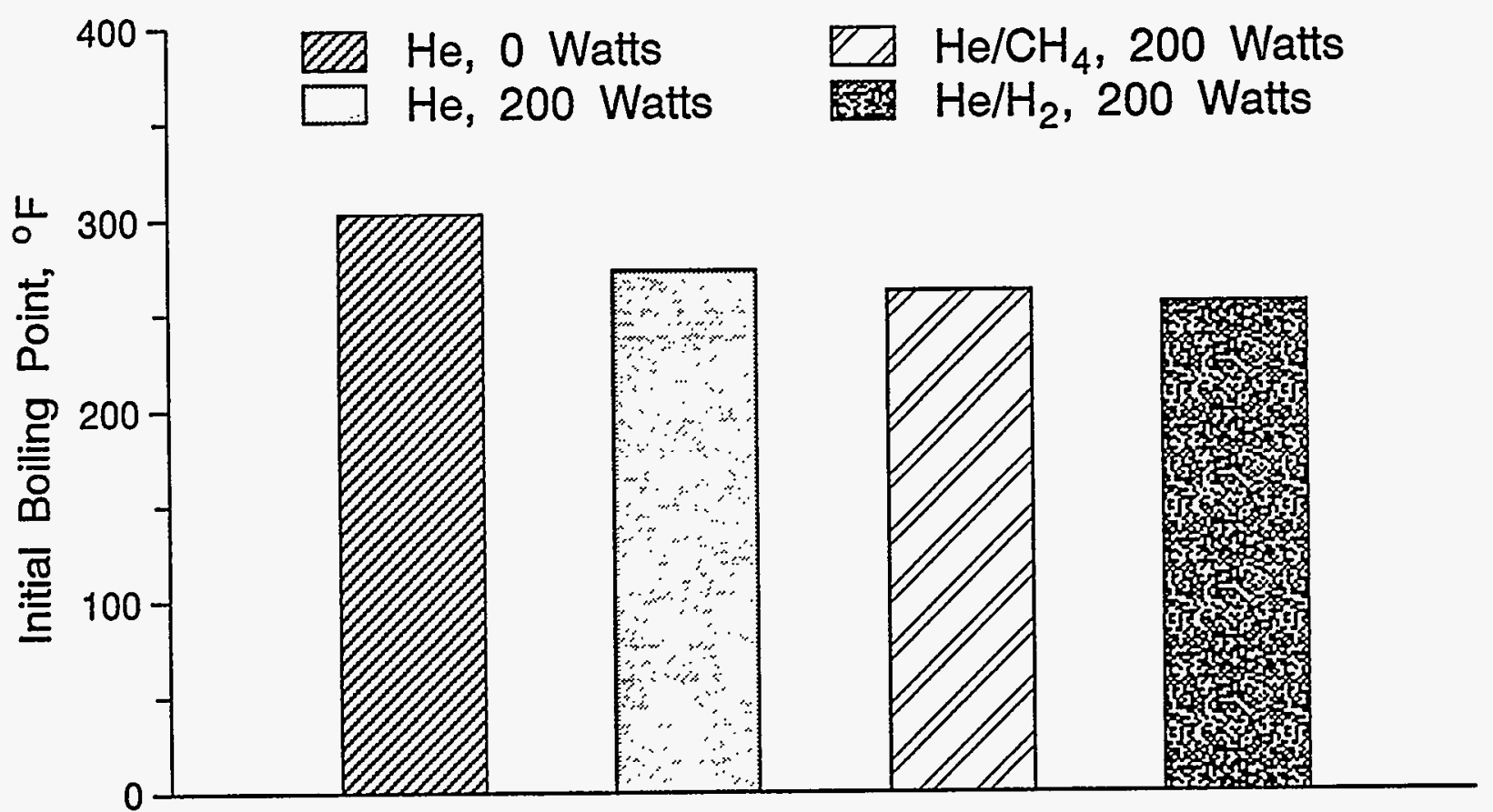

Figure 3. Initial Boiling Points for Plasma Produced Distillates 


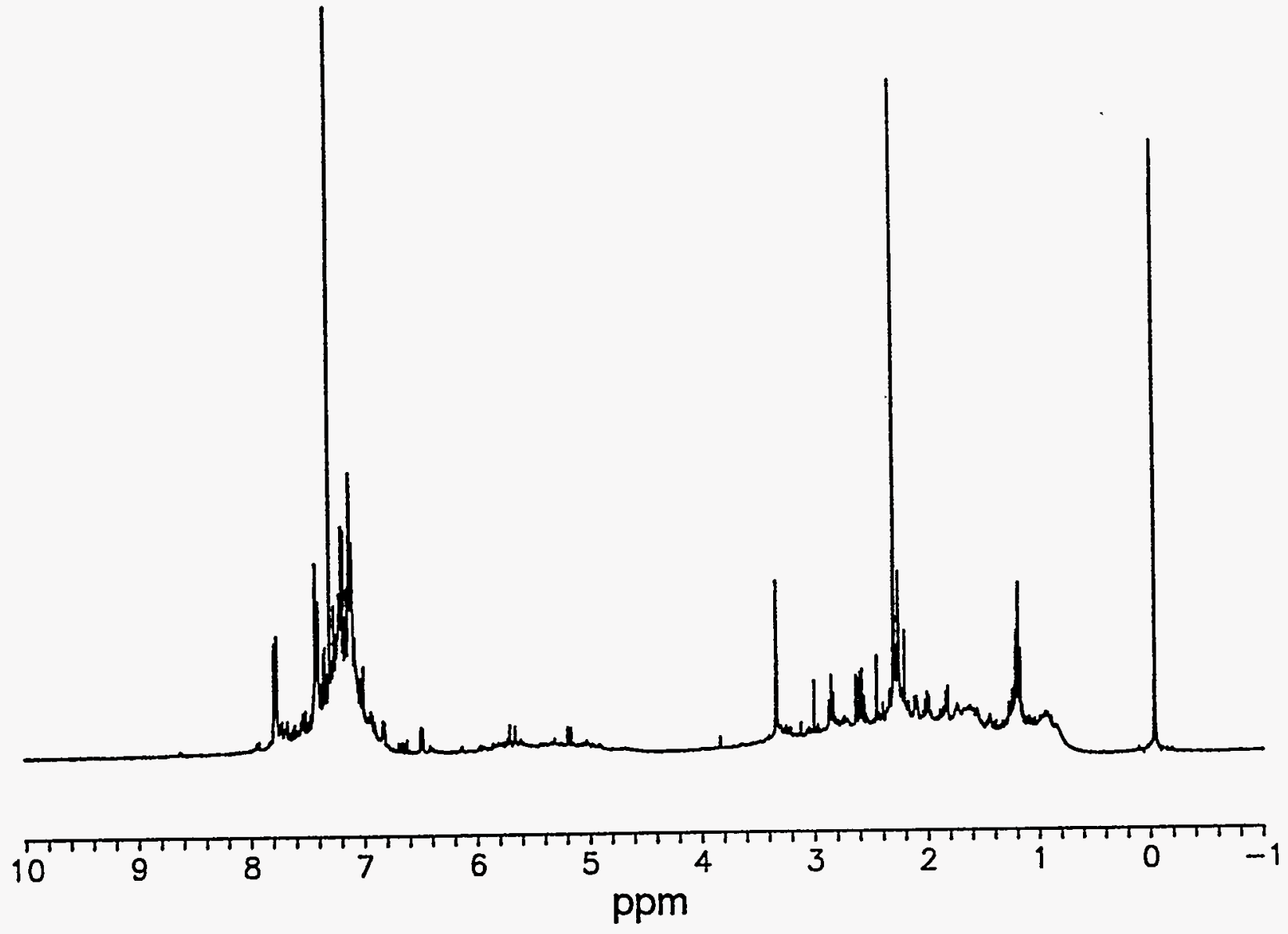

Figure 4. ${ }^{1} \mathrm{H}$ NMR Spectrum of Liquids Produced from a Methane Plasma 


\title{
6.0 REMEDIATION
}

\section{SUBTASK 6.1}

\section{NORTH SITE REMEDIATION}

\author{
Norm Merriam
}

August - October 1994

\section{OBJECTIVES}

The overall objectives of this subtask are to cleanup the WRI north site in a cost effective and environmentally sound manner. The objectives for the individual phases are:

Phase I - Definition of Waste Streams

Phase II - Disposal of Hazardous Wastes

Phase III - Disposal of Nonhazardous Wastes

Phase IV - Sampling of Soil and Removal of Buried Wastes

Phase V - Decontamination and Removal of Equipment

Phase Va - Groundwater Monitoring

\section{QUARTER OBJECTIVES}

Our objectives for the August through October period were the following.

- Complete shipment of liquid wastes except for rinsates.

- Clean and dismantle the shale oil storage tanks.
- Start dismantling the 136-tonne (150-ton) retort.

- Drill two groundwater monitoring wells and sample the water.

\section{ACCOMPLISHMENTS}

- Phase $I$ is complete.

- Phase $I$ is about $90 \%$ complete. We have now shipped all of the liquid from the site except the rinsate from drum cleaning and the sludge and wash water from cleanout of the shale oil storage tanks. We have 32 drums of sludge, wash water, contaminated diesel fuel, and cleaning debris to ship. The composite samples of these materials have been analyzed and are being profiled prior to disposal in mid November.

- Phase III is about $95 \%$ complete. We have only a small amount of surface contouring, some seeding, and preparation of the final report remaining in this phase.

- Phase IV is complete except for the final report. A draft of the report for Phase IV is nearly through the WRI editing process and will be shipped to DOE within a few weeks. 
- Phase $\mathrm{V}$ is about $60 \%$ complete. The shale oil storage tanks have been cleaned, dismantled, and the scrap metal has been hauled from the site. Dismantling of the 136-tonne (150-ton) retort is about $70 \%$ complete. Nelson-Clark Remediation has dismantled the metal containment ring from the former evaporation pond. We have not yet started to dismantle the 9.1tonne (10-ton) retort.

- Phase Va - Groundwater Monitoring is about 50\% complete. The two groundwater monitoring wells are in place and we have submitted the first set of water samples for analyses. Inorganics are being analyzed by SVL Analytical and organics by Datachem, both of which are EPA contract laboratories.

\section{ACTIVITIES FOR NEXT QUARTER}

- Complete dismantling of the 136-tonne (150-ton) retort.

- Ship the 32 drums of rinsate and sludge remaining on site. 


\section{CONTRACT STATUS REPORT}

Contract No:

Client:

Contract Start:

Contract Complete:

Reporting Period:
DE-FC21-93MC30126

U.S. Department of Energy

February 2, 1993

February 1, 1998

Year 2 (Including Cleanup Subtask)

\section{CUMULATIVE ACCRUED EXPENDITURES (\$)}

\begin{tabular}{lrrrrr} 
& Quarter 1 & & Quarter 2 & Quarter 3 & Quarter 4 \\
\cline { 2 - 2 } & 588,722 & $1,177,454$ & & $1,766,181$ & $2,354,908$ \\
Expenditures & 381,979 & 788,821 & $1,230,117$ & \\
Remaining Budget & $1,972,929$ & $1,566,087$ & $1,124,791$ &
\end{tabular}

EXPENDITURES VERSUS APPROVED BUDGET

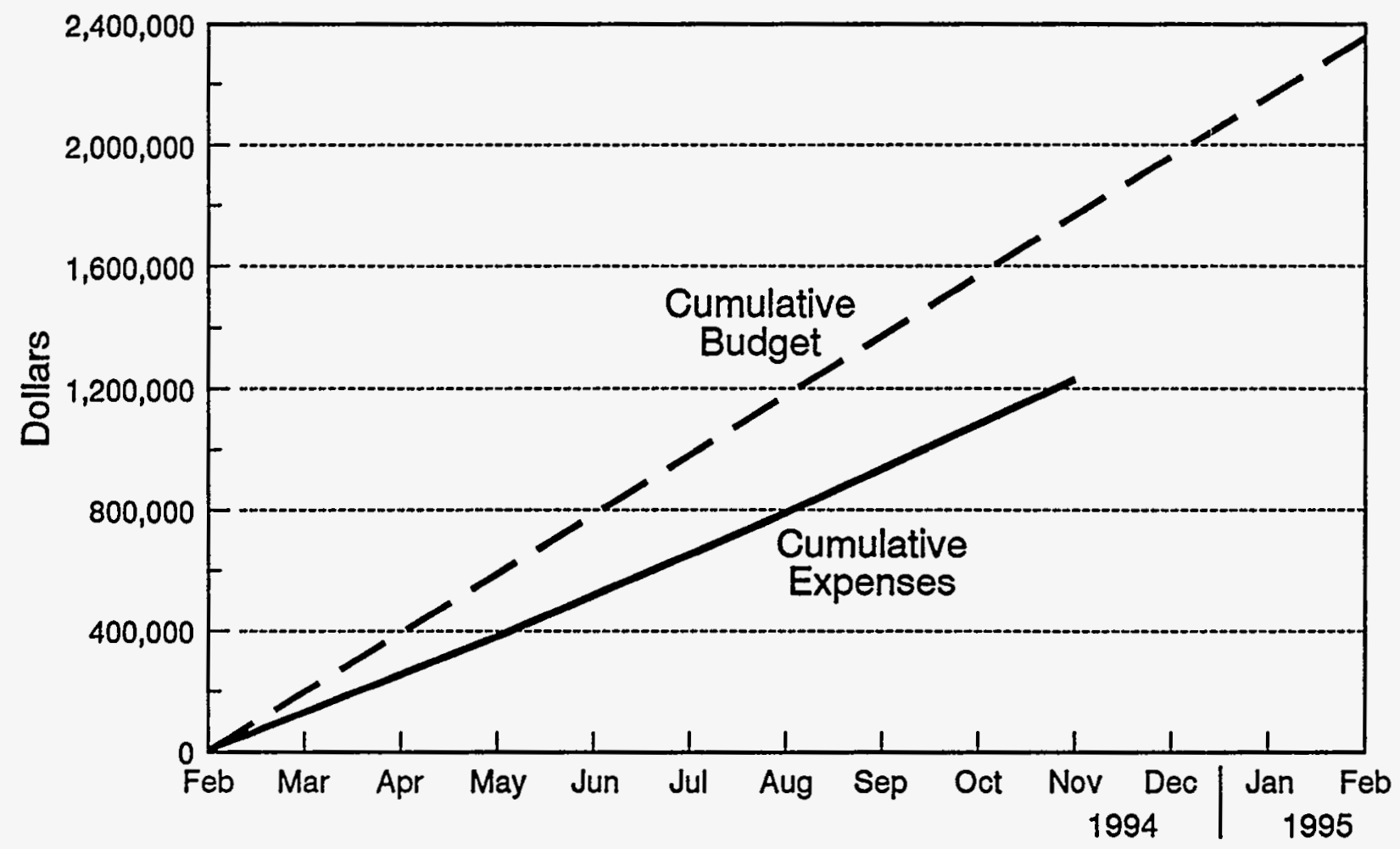


SUBTASK PROJECT SCHEDULE - YEAR 2

Cooperative Agreement DE-FC21-93MC30126

\begin{tabular}{|c|}
\hline Subtask \\
\hline 1.1 CROW'M Process Modeling \\
93-1.1.2 Physlcal Simulatlons \\
93-1.1.3 Model Vertication \\
94-1.1.1 Model Documentation \\
94-1.1A Toplcal Report
\end{tabular}

1.3 Portable Data Aquisition System and Coalbed Methane Simulator 83-1.3.1 Date System/Fleld Testing 93-1.3.2 SImulator Devalopment 93-1.3.3 Laboratory Work 93-1.3A Simulator System Report 93-1.3B Topical Report

1.4 Investigation of Tank Bottom Waste Processing Using the Waste Processing U
TaBoRR 94-1.4,1 Technology Support 94-1.4.2 Design, Const, \& Oper. 94-1.4.3 Modeling \& Econ. Anal. 94-1.4.4 Management \& Reporting 94-1.4A Experimental Plan 94-1.4B Toplcal Report

2.1 Development and Optimization of a Process for the Production of a a Process lor the production of a U.S. Coals 83-2.1A Experimental Plan 93-2.18 Toplcal Report

2.3 Optimization of the Recycle Oil Process for Eastern Oil Shale 93-2.3B Topical Report

2.4 Process Support \& Development 93-2.4.1 Statement of Work 93-2.4.2 Project Management 93-2.4.3 Reporting 93-2.4A Topical Report

2.5 Development of an Eastern Shale Oll Residue as an Asphalt Additive

94-2.5 Asphatt Additive Research 94-2.5A Experimental Plan 94-2.5B Toplcal Report

3.1 Solld Waste Management 93-3.1A Toplcal Report 84-3.1.1 Evaluation of CCT Ashes 94-3.1.2 Hydration Reactions 94-3.1.3 Control of Hyd. Reactions 95-3.1.4 Eflect of Cond. Media 95-3.1.5 CLSFFM Development 95-3.1.6 Management \& Reporting 85-3.1A Topical Report

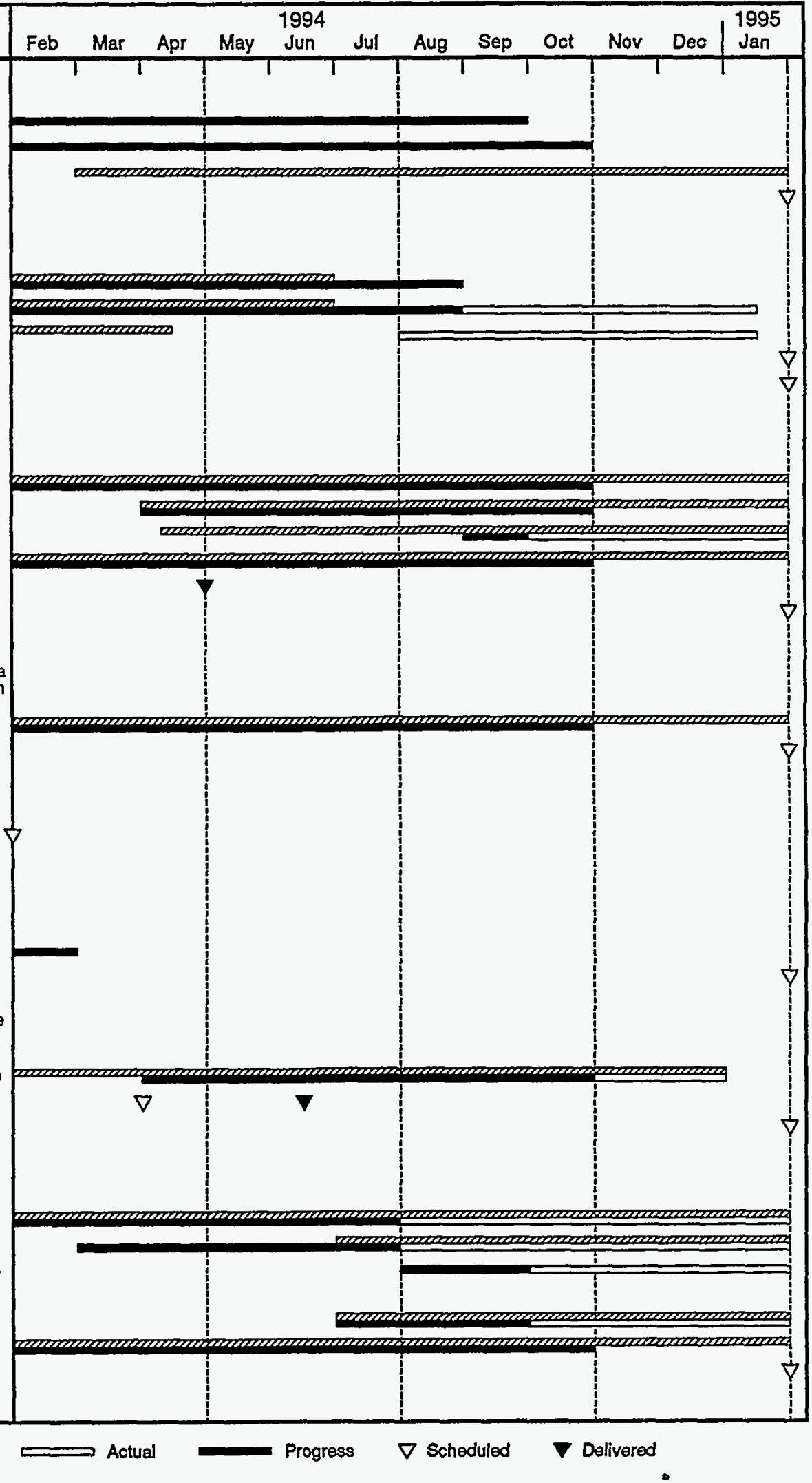


SUBTASK PROJECT SCHEDULE - YEAR 2 (CONTINUED)

Cooperative Agreement DE-FC21-93MC30126

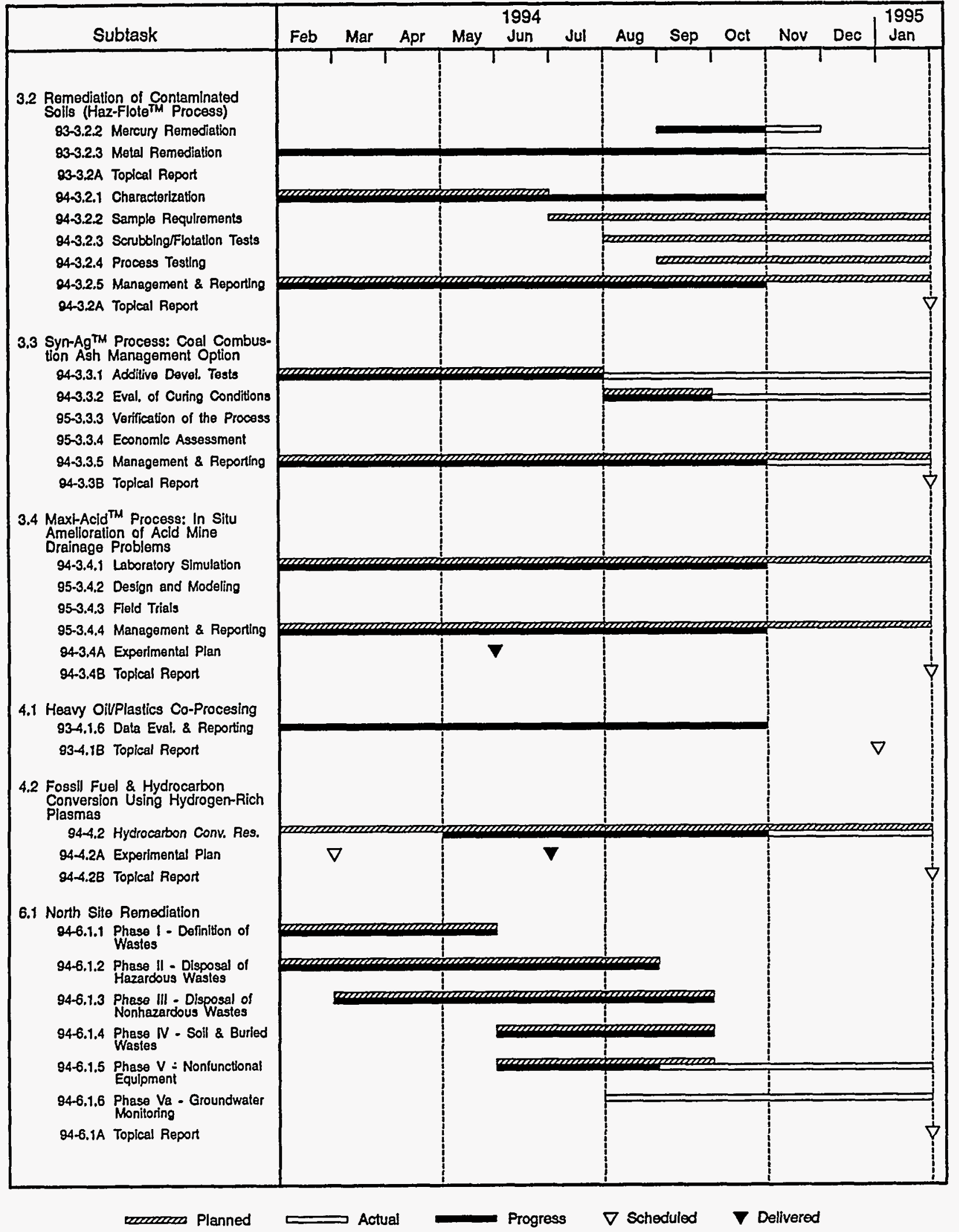




\section{DISCLAIMER}

Mention of specific brand names or models of equipment is for information only and does not imply endorsement of any particular brand. 